\title{
Az Egészségügyi Felvilágosítástól az Egészségfejlesztésig
}

\author{
The history of the Journal of Health Promotion
}

doi: 10.24365/ef.v60i1.433

Az Egészségfejlesztés folyóirat a 60. évébe lépett, ennek okán az idei év az ünneplés jegyében telik majd. Az 1960-ban indult lap több néven is megjelent, először Egészségügyi Felvilágosítás címmel, majd 1976-tól az Egészségnevelés címet viselte. A lap alapítói, dr. Métneki János és dr. Vimon Gyula az 1887-től az Országos Közegészségi Egyesület hivatalos lapjaként megjelenő Egészség című folyóirat szellemi folytatásaként tekintettek a lapra. A folyóirat 2004 óta már Egészségfejlesztés címen olvasható, 2016-tól pedig modern formában, elektronikusan jelenik meg. Büszkén mondhatjuk, hogy a hazai népegészségügyi szakfolyóiratok közül elsőként, csak szakbírálaton átesett (peer-reviewed) eredeti közleményeket jelentet meg, az egészségfejlesztés területéről származó legfrissebb hírek, fejlesztések, érdekességek, beszámolók, vélemények és megvitatásra érdemes kérdések felvetése mellett.

Célunk az egészségügyön kívüli, az egészségfejlesztésben érintett más ágazatok szakembereinek, így az oktatás, szociális szféra, közgazdaságtan, szociológia, média, urbanisztika stb. képviselőinek megszólítása, határterületi kérdésekről szóló cikkek megjelentetése is.

Az évforduló kapcsán számos, az elmúlt évtizedekben megjelent cikket dolgozunk fel újra a 2019-ben megjelenő lapszámokban, őszre pedig olvasói találkozót tervezünk. A szokásos négy szám mellett idén is két különszámmal jelentkezünk majd, az egyik az egészségtervezés témáját fogja taglalni, a másik - ehhez kapcsolódva - egy városi egészségtervezést fog részletesebben bemutatni.
A tavalyi év végén olvasói szavazást indítottunk „2018. legjobb cikkének” kiválasztására. A szavazáson első helyen végzett AGORA rovatban megjelent közlemény a gyermekbántalmazás magyarországi helyzetét és a prevenciós munka fontosságát mutatja be. A felhívásnak megfelelően a cikk első szerzőjével készített interjúnkat „A bántalmazás megelőzését a nyílt társadalmi kommunikáció segíti..." címmel a szerkesztőségi közlés rovatban olvashatják.

A folyóirathoz benyújtott kéziratok száma egyenletesen gyarapodik, ezzel együtt a közlemények megjelentetésével járó feladatok is növekednek. Szerkesztőségünk így új tagokkal bővült: év elejétől három új szerkesztőnk és két új olvasószerkesztőnk szerkeszti a lapot. A lap olvasói bázisa folyamatosan bővül, az olvasottsági adatok is a lap egyre növekvő ismertségét támasztják alá. A látogatói és olvasottsági statisztikákat a megszokott táblázatban és ábrán mutatjuk be részletesen alább.

Látható, hogy a TOP 10-es rangsorban nincs jelentős változás az előző számokhoz képest, így a legolvasottabb cikkek jellemzően tartják jó olvasottsági eredményüket. Érdekes viszont az, hogy egy tematikus válogatás is szerepel már a 10 „legérdekesebbnek" bizonyult cikk között - érdekességmutató: a megtekintések száma és a megjelenés óta eltelt napok száma hányadosa alapján számított mutató -, ami arra enged következtetni, hogy érdemes hasonló, szakterületekre fókuszáló cikkgyűjteményeket közölni. 


\begin{tabular}{|c|c|c|c|}
\hline \multicolumn{2}{|c|}{$\begin{array}{l}\text { Megtekin- } \\
\text { tések } \\
\text { száma }\end{array}$} & Szerzők & Lapszám \\
\hline \multicolumn{2}{|c|}{ ÖSSZEFOGLALÓ } & & \\
\hline 707 & Egészséges életmóddal kapcsolatos kutatások a hazai iskolákban & $\begin{array}{l}\text { Járomi É, Szilágyi K, } \\
\text { Vitrai J }\end{array}$ & 2016. 1. \\
\hline 599 & A kortársbántalmazás (bullying) mint népegészségügyi probléma & $\begin{array}{l}\text { Várnai } D, \text { Zsíros } E \text {, } \\
\text { Németh Á }\end{array}$ & 2016. 4. \\
\hline 581 & Hazai egészség-pillanatkép, 2017 & $\begin{array}{l}\text { Vitrai J, Bakacs M, } \\
\text { Varsányi P }\end{array}$ & 2017. 4. \\
\hline 512 & $\begin{array}{l}\text { A 2015/2016. tanév országos fittségmérési eredményei a Nemzeti Egységes Ta- } \\
\text { nulói Fittségi Teszt (NETFIT }{ }^{\circledR} \text { ) alapján }\end{array}$ & Csányi T, Kaj M & 2017. 4. \\
\hline 487 & $\begin{array}{l}\text { A gyógytestnevelés jelentősége a szekunder rehabilitáció és egészségfejlesztés } \\
\text { folyamatában, megújulásának szükségessége, irányai }\end{array}$ & Simon I, Kajtár G & 2018. 1. \\
\hline 452 & $\begin{array}{l}\text { Kortárs egészségfejlesztési programok gyermekek és fiatalok körében a hazai és a } \\
\text { nemzetközi szakirodalom tükrében - Szisztematikus áttekintés }\end{array}$ & Lukács-Jakab Á et al. & 2018. 1. \\
\hline 442 & $\begin{array}{l}\text { Egészpályás letámadás a kövérség ellen - Komplex beavatkozásokkal az elhízás } \\
\text { visszaszorítására }\end{array}$ & Vitrai J, Bakacs M & 2017. 4. \\
\hline 432 & $\begin{array}{l}\text { Magyarország népegészségügyi rendszere és egészségfejlesztéssel foglalkozó } \\
\text { szervezetei }\end{array}$ & Túri G et al. & 2018. 2. \\
\hline 418 & A magyarországi egészségértés nemzetközi összehasonlításban & Kolta J, Kun E & 2016. 3. \\
\hline 416 & Új hazai egészségmonitorozási koncepció & Varsányi P et al. & 2016. 1. \\
\hline \multicolumn{4}{|c|}{ TELES KÖZLEMÉNY } \\
\hline 2901 & A csecsemőkori allergia-megelőzés korszerú irányelvei és lehetőségei & Réthy A & 2017. 1. \\
\hline 1144 & Egészségfejlesztési Irodák hálózata & Bezzegh P & 2016. 1. \\
\hline 930 & Egészséges életmóddal kapcsolatos kutatások a hazai iskolákban & $\begin{array}{l}\text { Járomi É, Szilágyi K, } \\
\text { Vitrai J }\end{array}$ & 2016. 1. \\
\hline 632 & Hazai egészség-pillanatkép, 2017 & $\begin{array}{l}\text { Vitrai J, Bakacs M, } \\
\text { Varsányi P }\end{array}$ & 2017. 4. \\
\hline 595 & OKOSTÁNYÉR ${ }^{\circledR}$ - új táplálkozási ajánlás a hazai felnőtt lakosság számára & Szücs Zs & 2016. 4. \\
\hline 461 & $\begin{array}{l}\text { Magyarország népegészségügyi rendszere és egészségfejlesztéssel foglalkozó } \\
\text { szervezetei }\end{array}$ & Túri G et. Al & 2018. 2. \\
\hline 365 & Az iskolai egészségfejlesztés hazai és nemzetközi szemléletének bemutatatása & Járomi É, Vitrai J & 2017. 1. \\
\hline 357 & $\begin{array}{l}\text { Összefoglaló „A munkahelyi egészségfejlesztés általános szervezeti megvalósítá- } \\
\text { sára vonatkozó szakmai útmutató”-ról }\end{array}$ & Solymossy J, Koós T & 2016. 3. \\
\hline 351 & Amerikai Táplálkozási Ajánlás 2015-2020 - rövid ismertetés & Fekete K, Henter I & 2016. 2. \\
\hline 331 & 2016-os Éves Jelentés a kábítószerhelyzetről - rövid összefoglaló & Nyírády A & 2016.4. \\
\hline \multicolumn{4}{|c|}{ "ÉRDEKESSÉG" } \\
\hline 4,09 & A csecsemőkori allergia-megelőzés korszerú irányelvei és lehetőségei & Réthy A & 2017. 1. \\
\hline 1,55 & $\begin{array}{l}\text { Magyarország népegészségügyi rendszere és egészségfejlesztéssel foglalkozó } \\
\text { szervezetei }\end{array}$ & Túri G et al. & 2018. 2. \\
\hline 1,43 & Hazai egészség-pillanatkép, 2017 & $\begin{array}{l}\text { Vitrai J, Bakacs M, } \\
\text { Varsányi P }\end{array}$ & 2017. 4. \\
\hline 1,42 & Tematikus cikkválogatás az egészséges táplálkozás területéről & szerkesztőség & 2018. 6. \\
\hline 1,27 & Az egészségjelentések jó gyakorlata - irányelvek és ajánlások & Vitrai J. & 2018. 6. \\
\hline 1,11 & Egészségfejlesztési Irodák hálózata & Bezzegh P & 2016. 1. \\
\hline 1,08 & A családi tradíció szerepe a kisdedek és kisgyermekek táplálkozásában & $\begin{array}{l}\text { Karácsonyi I, Kölkedi } \\
\text { P, Karamánné Pakai } \\
\text { A }\end{array}$ & 2018. 5. \\
\hline 1,08 & Az anyai attitűdöt befolyásoló családi tényezők & $\begin{array}{l}\text { Pachner O, Lendvay } \\
\text { Zs }\end{array}$ & 2018. 5. \\
\hline 1,04 & $\begin{array}{l}\text { Cikkismertetés: A hat- és hétéveseket célzó, elhízást megelőző iskolai programok } \\
\text { hatékonyságának randomizált, ellenőrzött klasztervizsgálata (WAVES vizsgálat) }\end{array}$ & Erdei G & 2018. 6. \\
\hline
\end{tabular}


1. ábra: folyóirat honlapját havonta, illetve naponta átlagosan meglátogatók száma

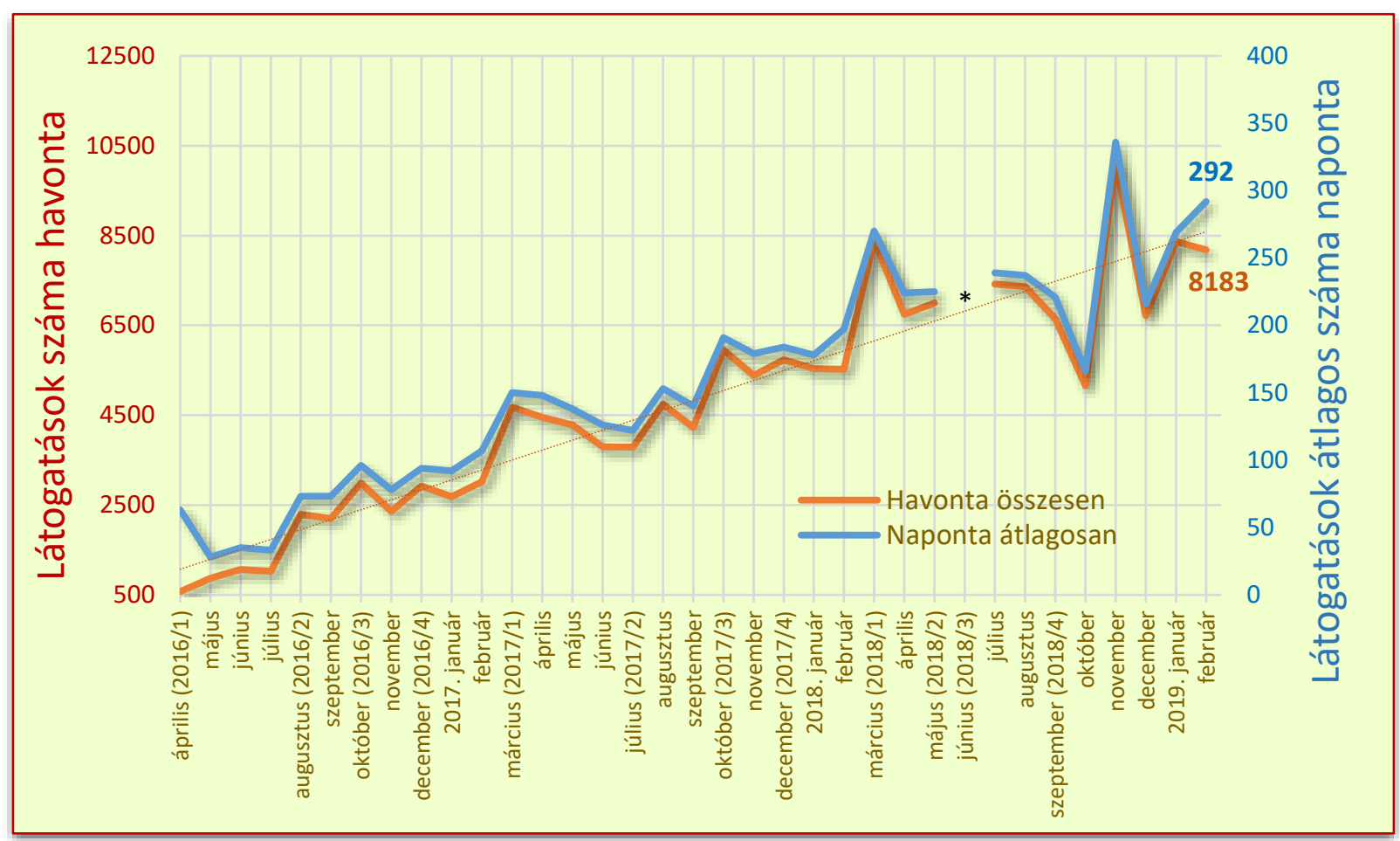

* nincs adat 